IZA DP No. 4382

Does the Choice of Reference Levels of Education Matter in the ORU Earnings Equation?

Barry R. Chiswick

Paul W. Miller

August 2009 


\title{
Does the Choice of Reference Levels of Education Matter in the ORU Earnings Equation?
}

\author{
Barry R. Chiswick \\ University of Illinois at Chicago \\ and IZA \\ Paul W. Miller \\ University of Western Australia \\ and IZA
}
Discussion Paper No. 4382
August 2009

IZA
P.O. Box 7240
53072 Bonn
Germany

Phone: +49-228-3894-0

Fax: +49-228-3894-180

E-mail: iza@iza.org

Any opinions expressed here are those of the author(s) and not those of IZA. Research published in this series may include views on policy, but the institute itself takes no institutional policy positions.

The Institute for the Study of Labor (IZA) in Bonn is a local and virtual international research center and a place of communication between science, politics and business. IZA is an independent nonprofit organization supported by Deutsche Post Foundation. The center is associated with the University of Bonn and offers a stimulating research environment through its international network, workshops and conferences, data service, project support, research visits and doctoral program. IZA engages in (i) original and internationally competitive research in all fields of labor economics, (ii) development of policy concepts, and (iii) dissemination of research results and concepts to the interested public.

IZA Discussion Papers often represent preliminary work and are circulated to encourage discussion. Citation of such a paper should account for its provisional character. A revised version may be available directly from the author. 
IZA Discussion Paper No. 4382

August 2009

\section{ABSTRACT \\ Does the Choice of Reference Levels of Education Matter in the ORU Earnings Equation?*}

This paper examines whether the results of the earnings equation developed in the overeducation/required eduation/under-education (ORU) literature are sensitive to whether the usual or reference levels of education are measured using the Realized Matches or Worker Self-Assessment methods. The analyses are conducted for all male native-born and immigrant workers in the US, by level of skill, and by occupation. While point estimates differ, particularly when earnings equations are estimated for the smaller samples of sub-groups of the workforce, the general findings are robust to this measurement issue. Thus, the answers provided to the typical research questions in the ORU literature on the utilization of schooling are independent of the measure of the usual or reference level of education used in the analyses.

JEL Classification: $\quad$ I21, J24, J31, J61, F22

Keywords: immigrants, skill, schooling, occupations, earnings, rates of return

Corresponding author:

Barry R. Chiswick

Department of Economics

College of Liberal Arts and Sciences

601 S. Morgan Street

Chicago, IL 60607-7121

USA

E-mail: brchis@uic.edu

\footnotetext{
* We thank Derby Voon for research assistance. Miller acknowledges financial assistance from the Australian Research Council.
} 


\section{DOES THE CHOICE OF REFERENCE LEVELS OF EDUCATION MATTER IN THE ORU EARNINGS EQUATION?}

\section{INTRODUCTION}

A cursory examination of recent issues of journals reveals that researchers are making increasing use of the over-education/under-education concepts. These first came to prominence in the early 1980s (see, for example, Duncan and Hoffman, 1981), and their analytical value was illustrated clearly in the papers in the 2000 April Special Issue of the Economics of Education Review on Overschooling. Since then there has been a steady stream of papers on the topic in this and other journals.

This literature proposes that there is a "usual" education level for each

occupation. ${ }^{1}$ Some workers will have this level of education, and be therefore regarded as being correctly matched to the typical educational requirements of their job. Other workers will have a higher level of education than that which is usual in their job. These workers with surplus years of schooling are viewed as being over-educated. Still other workers will have a lower level of education than that which is usual in their job, and hence are referred to as under-educated.

Central to the empirical application of the over-education/under-education concepts is a measure of the usual or reference level of schooling for an occupation. Three methods have been used to determine level of schooling: a Realized Matches (RM) method, a Worker Self-Assessment (WSA) method, and a Job Analysis (JA) method. Each of these has strengths and weaknesses, and their relative merits are discussed in

\footnotetext{
${ }^{1}$ The respondent's occupation is typically taken as exogenous in this literature. The ORU literature variously uses the terms "usual", "reference" and "required" years of schooling to represent the central tendency of the schooling level in the respondent's occupation. As the literature has not settled on the specific terminology these terms are used interchangeably in this paper as well.
} 
Hartog (2000) and Chiswick and Miller (2008). Importantly, Hartog (2000, p.135), having reviewed the empirical evidence on earnings effects from a wide range of studies, and offering three summary conclusions ${ }^{2}$, stated:

These conclusions are not sensitive to the measure of required education. We have results for all three measures of required education: job analysis, worker assessment and realized matches....The three conclusions given above hold independent of the type of measurement.

Hartog's (2000) analysis was based on secondary examination of findings. Only two of the many studies documented had direct comparison of the performance of the measures of usual or required education. Santos (1995) used both RM and JA methods in a study for Portugal (See also Kiker, Santos and de Oliveira (1997).). Rumberger (1987) used the WSA and JA methods in a study for the US. The most recent data employed in Santos (1995) were for 1991, whereas the most recent data in the study by Rumberger (1987) were for 1973. Comparisons were offered for males and females separately.

This paper provides a more recent assessment of this issue, using data from the 2000 US Census and the O*NET data base. ${ }^{3}$ Analyses are conducted for all adult male native-born and immigrant workers in the US. The enquiry is "research question driven". Thus, the analyses provide answers to three questions: (i) Are there effects on earnings from being under-educated, over-educated or correctly-matched to the educational

\footnotetext{
${ }^{2}$ The three conclusions are: (i) the returns to required schooling exceed the returns to actual education; (ii) returns to surplus schooling are positive, but smaller than that to the returns to required schooling; and (iii) returns to under-education are negative, but of a smaller absolute magnitude than the returns to required education.

${ }^{3}$ The National O*NET Consortium was organized to accomplish the development of O*NET and its related products for the US Department of Labor, Employment and Training Administration. See the O*NET website: http://online.onetcenter.org.
} 
requirements of one's job in the US labor market?; (ii) Do the earnings effects in (i) vary according to the level of aggregation in the data?; and (iii) Are there sectors of the labor market where surplus skills can be used relatively more effectively. This paper focuses on whether the answers to these research questions are sensitive to whether the RM or WSA measure is used for the usual or reference level of education in the ORU model. Given the data sources used in this project, it is not possible to test the sensitivity of the JA approach.

The paper is structured as follows. Section II provides a brief outline of the Overeducation/Required Education/Under-education earnings function, and reviews Hartog’s (2000) earlier findings. Section III presents information on the data set used. The empirical results are presented and discussed in Section IV. Concluding comments are offered in Section V.

\section{LITERATURE REVIEW}

The over-education/under-education literature has focused on two primary issues. The first is whether workers are over-educated, under-educated or correctly matched given the usual educational requirements of their occupation. The second issue concerns the impacts on earnings of educational mismatches. The latter research has been based on a variant of the human capital earnings function that has been termed the ORU (Overeducation/Required education/Under-education) specification. In this model, the dependent variable is the natural logarithm of earnings $\left(\ln Y_{i}\right)$ and the variable for actual years of education is decomposed into three terms. Thus,

(1) $\ln Y_{i}=\alpha_{0}+\alpha_{1}$ Over_Educ $_{i}+\alpha_{2}$ Req_Educ $_{i}+\alpha_{3}$ Under_Educ $_{i}+\ldots+u_{i}$ 
where

Over_Educ = years of surplus or over-education,

Req_Educ = the usual or reference years of education,

Under_Educ $=$ years of deficit or under-education,

and the actual years of education equals Over_Educ + Req_Educ - Under_Educ. Note that for each individual, “Over_Educ" and "Under_Educ" cannot both be positive. Either one or both must be zero. Equation (1) will also contain other variables generally included in earnings functions, such as potential labor market experience, marital status, location, race/ethnicity, veteran of the US Armed Forces, and variables specific to the foreign born, such as duration of residence in the US, citizenship status and sometimes specific country of origin.

In most studies equation (1) is estimated on samples of all workers, though separate analyses have been undertaken for particular groups of interest. For example, Chiswick and Miller (2008) conduct separate analyses for foreign-born and native-born male workers. Rumberger (1987) reported findings from estimations undertaken on separate samples of men and women. Duncan and Hoffman (1981) present results for four gender-race groups (White men, Black men, White women, Black women). Some analyses extend the disaggregation of the sample beyond that based on nativity, gender or race to consider occupations and skill level. Rubb (2003), Rumberger (1987), Vahey (2000), Verdugo and Verdugo (1989) and Chiswick and Miller (2008, 2009) are examples.

All studies report that there is a high incidence of educational mismatches in the labor market. Hartog (2000, p.133) surmises “It’s fairly common to find a proper match in about $60 \%$ of the cases...”. This matching and mismatching has been shown to matter 
in the study of earnings. Hartog (2000, p. 135). These earnings effects, however, have been shown to vary by gender, nativity, occupation and skill level (see Rumberger, 1987; Hartog, 2000; Vahey, 2000; Chiswick and Miller, 2008). The gender effects have been shown to be robust to the measurement of mismatches, though this issue has not been examined in relation to nativity, occupation and skill level. ${ }^{4}$

\section{MEASUREMENT OF MISMATCHES AND DATA}

The analyses reported below are based on two data sources: the 2000 US Census five percent Public Use Microdata Sample, and the Occupational Information Network, or O*NET, database. The 2000 Census is the source for the information on labor market earnings, human capital and demographic characteristics (educational attainment, age, marital status, veteran of US Armed Forces, English proficiency, race/ethnicity, location, and among the foreign born, citizenship and duration of residence in the US). ${ }^{5}$ While this data source covers the entire population, the analyses are based on men aged 25 to 64 years who were employed and had non-zero earnings in 1999. Separate analyses are conducted for native-born workers and for foreign-born workers. For each of these nativity groups the analyses are also conducted by occupation and by skill level. When

\footnotetext{
${ }^{4}$ Kler (2005) used both the RM and JA procedures in an analysis of the earnings of native-born graduates in the Australian labor market in 1996. He reports that the findings are sensitive to the method used for the reference level of education. This is consistent with the findings in this study, to the effect that the more narrowly defined the sample analyzed, and hence the smaller the sample size, the more variability there is across the findings for the alternative ways of constructing the reference levels of education. There are several other studies that offer comparisons of the JA, RM and WSA measures, but these do not analyze earnings (see, for example, Tsang, Rumberger and Levin, 1991 and Alpin, Skackleton and Walsh, 1998).

${ }^{5}$ As all analyses are conducted using the 5 percent PUMS, only a random subset (0.15) of the native-born workers in this file is used.
} 
the O*NET data base was first established, information from the Dictionary of Occupational Titles was used, and so it was based on a JA procedure. Since then this information has been replaced by the WSA information discussed below.

Two separate measures of the usual level of education are used. The first is the modal level of education of native-born workers in each of the approximately 500 occupations in the 2000 Census. The focus on native-born male workers is appropriate where the economic majority group sets the norm for all workers in the occupation. This will simply be referred to as the Realized Matches (RM) method, which reflects the outcome of the labor market process. This RM measure has the apparent advantage of offering a greater range than the WSA method described below in the usual years of education: it ranges from 12 years to Doctorate, with intermediate values of 14,16 (Bachelor's Degree), Masters Degree, and Professional Degree. 6

The second method is a WSA based on the O*NET database. This database categorizes occupations into five Job Zones. A job zone is a group of occupations that are similar in: (i) how most people get into the occupation; (ii) how much overall experience people need to do the work; (iii) how much education people need to do the work; and (iv) how much on-the-job training people need to do the work? The information on education was collected from surveys of workers using the question: "If someone were being hired to perform this job, indicate the level of education that would be required: (Note that this does not mean the level of education that you personally have achieved.)”

\footnotetext{
${ }^{6}$ Chiswick and Miller (2008) offer a comparative assessment of a number of ways of computing a RM measure. van der Meer (2006) compares two JA methods.
} 
There are five job zones in $\mathrm{O}^{*} \mathrm{NET}$ database: Job Zone 1 includes occupations that require little or no preparation (e.g., cashiers and dishwashers); Job Zone 2 covers occupations that require some preparation (e.g., security guards and telephone operators); Job Zone 3 contains occupations that require medium preparation (e.g., electricians and real estate brokers); Job Zone 4 consists of occupations that require considerable preparation (e.g., auditors and copy writers); and Job Zone 5 contains occupations that require extensive preparation (e.g., dentists and lawyers).

The educational requirement specified in each job zone can be synthesized into three broad groups namely, (a) high school diploma or GED certificate, (b) training in vocational schools, related on-the-job experience, or an associate's degree, and (c) fouryear bachelor's degree. All of these are considered the minimum level of educational attainment needed for a particular occupation. These categories have been converted into years of education to facilitate the empirical analyses. The conversion is shown in the table below:

\begin{tabular}{|ll|}
\hline Educational Category & Years of Education \\
\hline High School Diploma/GED Certificate & 12 \\
Vocational Schools & 14 \\
Bachelor's Degree (four-year) & 16 \\
\hline
\end{tabular}

As judgment has to be exercised in assigning a single schooling level for some occupations, two indices were compiled. The first is based on the highest level of schooling mentioned in the O*NET job description as being usual for the occupation. The second modifies the first in cases where several schooling levels were mentioned by focusing on the lowest level of schooling included in the description. The correlation 
coefficient across occupations between the two measures, however, is 0.98 , indicating that the choice of measure is not likely to impact the analysis.

There is a high degree of correlation between the WSA and RM data series, with the simple correlation coefficient between these measures being around 0.8 for all skillnativity groups considered, and being largely invariant to the changes to the WSA measure examined. At face value this suggests that the choice of WSA or RM data series should not matter in empirical analyses. This matter is investigated in the next section.

\section{STATISTICAL ANALYSIS}

The statistical analyses that follow focus on the determinants of earnings, which is the primary focus of the ORU literature. They are organized around the three research questions mentioned in the Introduction.

\section{A. Do Educational Matches and Mis-matches Affect Earnings?}

Table 1 presents results from an aggregate-level analysis of the determinants of earnings. This has separate panels for the native born and for the foreign born. The first column (i) of results for each birthplace group is for the standard schooling-experience earnings function. The second column (ii) of results is for the ORU specification, where the usual level of schooling for each occupation is given by the modal level of actual schooling of the native-born workers in that occupation. The third column (iii) of results is based on the WSA method. ${ }^{7}$

\footnotetext{
${ }^{7}$ The results for the WSA method are based on the highest usual level of schooling noted in the $\mathrm{O} * \mathrm{NET}$ job description. Using the lowest values where a range is presented does not have any major impact on the findings.
} 
Table 1

\section{Selected Estimates of Standard and ORU Models of Earnings by Nativity, 25-64 Year Old Males, 2000 US Census}

\begin{tabular}{|c|c|c|c|c|c|c|}
\hline \multirow[b]{2}{*}{ Variable } & \multicolumn{3}{|c|}{ Native Born } & \multicolumn{3}{|c|}{ Foreign Born } \\
\hline & $\begin{array}{l}\text { Standard } \\
\text { (i) }\end{array}$ & $\begin{array}{c}\text { RM } \\
\text { (ii) }\end{array}$ & $\begin{array}{l}\text { WSA } \\
\text { (iii) }\end{array}$ & $\begin{array}{l}\text { Standard } \\
\text { (i) }\end{array}$ & $\begin{array}{c}\text { RM } \\
\text { (ii) }\end{array}$ & $\begin{array}{l}\text { WSA } \\
\text { (iii) }\end{array}$ \\
\hline $\begin{array}{l}\text { Educational } \\
\text { Attainment }\end{array}$ & $\begin{array}{c}0.103 \\
(162.05)\end{array}$ & (a) & (a) & $\begin{array}{c}0.053^{*} \\
(144.99)\end{array}$ & (a) & (a) \\
\hline $\begin{array}{l}\text { Usual Level of } \\
\text { Education }\end{array}$ & (a) & $\begin{array}{c}0.151 \\
(203.53)\end{array}$ & $\begin{array}{c}0.170 \\
(196.44)\end{array}$ & (a) & $\begin{array}{c}0.156^{*} \\
(192.57)\end{array}$ & $\begin{array}{c}0.160 * \\
(183.80)\end{array}$ \\
\hline $\begin{array}{l}\text { Years of Over- } \\
\text { education }\end{array}$ & (a) & $\begin{array}{c}0.054 \\
(42.80)\end{array}$ & $\begin{array}{c}0.063 \\
(45.77)\end{array}$ & (a) & $\begin{array}{l}0.046^{*} \\
(43.25)\end{array}$ & $\begin{array}{l}0.056^{*} \\
(49.91)\end{array}$ \\
\hline $\begin{array}{l}\text { Years of Under- } \\
\text { education }\end{array}$ & (a) & $\begin{array}{l}-0.064 \\
(53.98)\end{array}$ & $\begin{array}{c}-0.071 \\
(73.77)\end{array}$ & (a) & $\begin{array}{l}-0.022^{*} \\
(47.61)\end{array}$ & $\begin{array}{l}-0.031^{*} \\
(70.35)\end{array}$ \\
\hline $\begin{array}{l}\text { Other controls } \\
\text { included }^{(b)}\end{array}$ & Yes & Yes & Yes & Yes & Yes & Yes \\
\hline Adjusted $R^{2}$ & 0.339 & 0.360 & 0.359 & 0.352 & 0.391 & 0.386 \\
\hline Sample Size & 368,855 & 368,855 & 368,855 & 388,784 & 388,784 & 388,784 \\
\hline
\end{tabular}

Source: 2000 US Census, 5\% PUMS.

Notes: Heteroskedasticity-consistent ' $\mathrm{t}$ ' statistics in parentheses; RM = Realized Matches, WSA = Worker Self-Assessment; * = Estimated coefficient for the foreign born is significantly different from that for the native born; (a) = Variable not entered; (b) = The other variables included in the estimating equation are: years of potential labor market experience and its square, weeks worked, marital status, resident of metropolitan area, resident of Southern state, English language proficiency, veteran of US Armed Forces, Black racial origin, and for the foreign born, citizenship and duration of residence in the US.

There are a number of interesting results obtained using the standard earnings function, though attention is only directed here to the return to schooling: for the native born this is 10.3 percent, and this is around double that for the foreign born, at 5.3 percent. $^{8}$

\footnotetext{
${ }^{8}$ The findings in the first two columns parallel those in Chiswick and Miller (2008). The minor differences between these results and those in Chiswick and Miller (2008) arise owing to the different samples (1 percent PUMS in Chiswick and Miller (2008) compared to the 5 percent PUMS in the current analysis), different sample exclusions (the occupations for which O*NET data could not be obtained-mainly the military occupations-are excluded from the current analysis but were included in the Chiswick and Miller (2008) study), and different variable definitions (the metropolitan variable is defined using the location identifiers specific to the 5 percent PUMS rather than the coarser identifiers on the 1 percent PUMS used in Chiswick and Miller (2008)), and the English Not Well and Not at All categories are combined in the current study to facilitate the disaggregated analyses by occupation that follow.
} 
The findings from the ORU model based on the RM procedure in the second column are consistent with the literature. Thus, years of education that are usual for the workers' occupations are associated with a higher return (15.1 percent for the native born and 15.6 percent for the foreign born) than years of actual schooling (10.3 percent and 5.3 percent for the native born and foreign born, respectively). ${ }^{9}$ Years of education that are surplus to the occupation are associated with a lower payoff, of 5.4 percent among the native born and of 4.6 percent among the foreign born. Thus, as has been noted in the over-education/under-education literature, it appears that occupations have specific educational requirements, and firms have difficulty utilizing effectively the skills of workers who have greater levels of education than is usual for their occupation. Years of under-education are associated with an earnings penalty (compared to years of correctly matched education) of 6.4 percent among the native born and 2.2 percent among the foreign born.

The findings for the ORU model based on the WSA method for assessing the usual years of schooling for each occupation are very similar to those obtained when the mode of schooling in each occupation is used for this purpose. Thus, the usual years of education for the occupation are associated with a payoff of 17.0 percent among the native born and 16.0 percent among the foreign born. Years of education that are surplus to the usual levels in an occupation are associated with only 6.3 percent higher earnings among the native born, and 5.6 percent higher earnings among the foreign born. Years of under-education are associated with an earnings penalty of 7.1 percent for the native born, and 3.1 percent for the foreign born. These estimated impacts are only one-to-two

${ }^{9}$ See Chiswick and Miller (2008) for an analysis of why the coefficient of actual schooling is so much smaller for the foreign born than for the native born. 
percentage points different from those reported for the RM method. Hence, even though fewer levels of schooling (just three) are used to index the usual levels under the WSA method than under the RM method (six), the two methods yield essentially the same results in this aggregate-level analysis.

In summary, the Table 1 results show that the major findings from the ORU model are not sensitive to the way the usual level of education for each occupation is compiled. This finding holds for both the analyses for the native born and for the foreign born. The extent to which this carries over to separate analyses by skill level, and by occupation, is examined below.

\section{B. Do the Effects of Educational Matches and Mis-matches Vary by Level of Disaggregation?}

Table 2 presents results from the estimation of the standard and ORU models of earnings determination on a sample restricted to workers with at least a Bachelor's degree. ${ }^{10}$ These results differ from those for the full sample in Table 1 in a number of respects. However, the focus of the discussion that follows will again be on the education variables.

First, the payoff to actual years of education is 11.1 percent for the native born and 10.6 percent for the foreign born. These estimates are greater than those for the full sample (of 10.3 and 5.3 percent, respectively), indicating a non-linearity in the returns to education, particularly among the foreign born.

\footnotetext{
${ }^{10}$ When the sample is restricted to skilled workers, under-education is not an issue: it is non-existent when the WSA measure is adopted, and negligible when the RM measure is used. Hence only results for the years of over-education variables are presented.
} 
Table 2

Selected Estimates of Standard and ORU Models of Earnings by Nativity, Skilled (Bachelor's or Higher Degree) 25-64 Year Old Males, 2000 US Census

\begin{tabular}{|c|c|c|c|c|c|c|}
\hline \multirow[b]{2}{*}{ Variable } & \multicolumn{3}{|c|}{ Native Born } & \multicolumn{3}{|c|}{ Foreign Born } \\
\hline & $\begin{array}{c}\text { Standard } \\
\text { (i) }\end{array}$ & $\begin{array}{l}\text { RM } \\
\text { (ii) }\end{array}$ & $\begin{array}{l}\text { WSA } \\
\text { (iii) }\end{array}$ & $\begin{array}{l}\text { Standard } \\
\text { (i) }\end{array}$ & $\begin{array}{l}\text { RM } \\
\text { (ii) }\end{array}$ & $\begin{array}{l}\text { WSA } \\
\text { (iii) }\end{array}$ \\
\hline Educational & 0.111 & (a) & (a) & 0.106 & (a) & (a) \\
\hline Attainment & (42.49) & & & (49.52) & & \\
\hline $\begin{array}{l}\text { Usual Level of } \\
\text { Education }\end{array}$ & (a) & $\begin{array}{c}0.122 \\
(47.85)\end{array}$ & $\begin{array}{c}0.200 \\
(68.20)\end{array}$ & (a) & $\begin{array}{l}0.140 * \\
(64.45)\end{array}$ & $\begin{array}{l}0.224 * \\
(89.25)\end{array}$ \\
\hline $\begin{array}{l}\text { Years of Over- } \\
\text { education }\end{array}$ & (a) & $\begin{array}{l}0.020 \\
(7.15)\end{array}$ & $\begin{array}{c}0.074 \\
(28.23)\end{array}$ & (a) & $\begin{array}{l}0.019 \\
(8.34)\end{array}$ & $\begin{array}{l}0.062^{*} \\
(29.12)\end{array}$ \\
\hline $\begin{array}{l}\text { Other controls } \\
\text { included }{ }^{(b)}\end{array}$ & Yes & Yes & Yes & Yes & Yes & Yes \\
\hline Adjusted $R^{2}$ & 0.230 & 0.259 & 0.260 & 0.278 & 0.322 & 0.329 \\
\hline Sample Size & 100,885 & 100,885 & 100,885 & 100,968 & 100,968 & 100,968 \\
\hline
\end{tabular}

Source: 2000 US Census, 5\% PUMS.

Notes: See Table 1.

The coefficients on the ORU variables in Table 2 differ by up to six percentage points compared to those in Table 1. Moreover, the estimated effects for those with at least a Bachelor's degree change in different directions under the RM and WSA methods of measurement compared to the Table 1 results for all workers. The payoff to years of usual education, as measured by the RM procedure, falls by several percentage points when the focus is on workers with at least a Bacherlor's degree. The payoff to years of usual education, as measured by the WSA procedure, increases by up to six percentage points when skilled workers are the focus. A similar pattern is found in the payoff to years of schooling that are surplus in the respondent's occupation. However, if the focus is simply on the Table 2 results, rather than on the Table 2 and Table 1 comparisons, the pattern in the findings based on each of the RM and WSA measures follows the expected patterns, though clearly the point estimates are sensitive to the choice of RM or WSA. 
Table 3 lists results for a more stringent definition of skilled workers, of workers with a Master's or higher degree. A review of these findings permits the same conclusion as offered in relation to Table 2. That is, regardless of whether the RM or WSA measure is used, the general patterns reported in the ORU literature are observed in the results. The WSA measure is associated with a relatively high payoff to required schooling, and this appears to be associated with the compression of the required levels of schooling at the upper end of the schooling distribution.

\section{Table 3}

Estimates of Standard and ORU Models of Earnings by Nativity, Highly-Skilled (Master's or Higher Degree) 25-64 Year Old Males, 2000 US Census

\begin{tabular}{|c|c|c|c|c|c|c|}
\hline \multirow[b]{2}{*}{ Variable } & \multicolumn{3}{|c|}{ Native Born } & \multicolumn{3}{|c|}{ Foreign Born } \\
\hline & $\begin{array}{l}\text { Standard } \\
\text { (i) }\end{array}$ & $\begin{array}{c}\mathbf{R M} \\
\text { (ii) }\end{array}$ & $\begin{array}{l}\text { WSA } \\
\text { (iii) }\end{array}$ & $\begin{array}{l}\text { Standard } \\
\text { (i) }\end{array}$ & $\begin{array}{c}\mathbf{R M} \\
\text { (ii) }\end{array}$ & $\begin{array}{l}\text { WSA } \\
\text { (iii) }\end{array}$ \\
\hline Educational & 0.110 & (a) & (a) & $0.055^{*}$ & (a) & (a) \\
\hline Attainment & (19.37) & & & (13.43) & & \\
\hline $\begin{array}{l}\text { Usual Level of } \\
\text { Education }\end{array}$ & (a) & $\begin{array}{c}0.132 \\
(23.67)\end{array}$ & $\begin{array}{c}0.245 \\
(34.31)\end{array}$ & (a) & $\begin{array}{l}0.091^{*} \\
(22.00)\end{array}$ & $\begin{array}{l}0.209 * \\
(41.47)\end{array}$ \\
\hline Years of Over- & (a) & 0.027 & 0.087 & (a) & $-0.018 *$ & $0.030 *$ \\
\hline education & & $(4.50)$ & (15.38) & & $(4.20)$ & $(7.04)$ \\
\hline $\begin{array}{l}\text { Other controls } \\
\text { included }^{(\mathrm{b})}\end{array}$ & Yes & Yes & Yes & Yes & Yes & Yes \\
\hline Adjusted $R^{2}$ & 0.221 & 0.251 & 0.246 & 0.269 & 0.307 & 0.313 \\
\hline Sample Size & 36,572 & 36,572 & 36,572 & 47,539 & 47,539 & 47,539 \\
\hline
\end{tabular}

Source: 2000 US Census, 5\% PUMS.

Notes: See Table 1.

C. $\quad$ Are Surplus Skills Used More Effectively in Some Sectors of the Labor Market?

(a) Analyses by Occupation

The standard earnings-experience earnings function, and the ORU equation with the alternative usual education variables (RM and WSA), were estimated within each of the Census major group occupations. These estimations are conducted for the group of 
skilled workers possessing Bachelor's or higher degrees. The main issue that researchers using analyses by occupation seek to address is whether there are some occupations where surplus skills can be used more effectively than elsewhere in the economy. One way this will be captured in the ORU model is via a smaller gap between the payoffs to the years of education that are usual for a worker's occupation and to years of education that are considered surplus in the occupation.

There are 23 Census major group occupations. However, as the WSA variable is not available for the military, only 22 occupations were included in the initial set of analyses undertaken. In one occupation (Community and Social Services) there was no variation in the usual level of schooling across its component occupations under the WSA procedure. There was no variation in the usual level of schooling in two other occupations (Building and Grounds Cleaning and Maintenance; and Farming, Fishing and Forestry) when the RM procedure was used. These three additional occupations were therefore omitted from the analyses undertaken in this sub-section, leaving 19 occupations.

The coefficients on the education variables (actual years of schooling, years of usual schooling, years of overeducation and years of undereducation) for each skillbirthplace group are presented in Appendix A. Results are shown for both the RM and WSA methods. Sets of simple correlations between the estimated coefficients on the various education variables are presented in Tables 4 and 5 . Figures below the diagonal in each of these tables are for the foreign born, and these are shaded; figures above the diagonal are for the native born. Correlations, computed separately for the foreign-born and native-born men, between the schooling coefficients and the mean level of schooling 
in the occupation are also provided to illustrate how these payoffs vary with the skill level of the occupation. The discussion here will address only these correlations.

Table $4^{(a)}$

\section{Correlation Coefficients among Payoffs of Education and Mean Level of Education from Analyses Disaggregated by Occupation, Skilled (Bachelor's or Higher Degree), Realized Matches Methodology, 25-64 Year Old Males, 2000 US Census}

\begin{tabular}{|l|ccccc|}
\hline FB $\backslash N B^{(b)}$ & EDUC & USUAL & OVER & GAP & MEAN \\
\hline EDUC & 1.00 & $0.52^{*}$ & 0.18 & 0.25 & $0.85^{*}$ \\
USUAL & $0.50^{*}$ & 1.00 & $0.45^{*}$ & 0.36 & 0.25 \\
OVER & $0.52^{*}$ & 0.10 & 1.00 & $-0.67^{*}$ & 0.08 \\
GAP & 0.12 & $0.80^{*}$ & $-0.52^{*}$ & 1.00 & 0.13 \\
MEAN & $0.74^{*}$ & 0.16 & 0.32 & -0.06 & 1.00 \\
\hline
\end{tabular}

Source: Appendix A.

Notes: (a) Based on Realized Matches procedure; (b) Shaded cells are correlations for the foreign born. EDUC=payoff to actual years of schooling; USUAL=payoff to usual years of schooling; OVER=payoff to years of surplus schooling; UNDER=earnings penalty to years of under-education; MEAN=mean educational attainment of occupation; GAP=difference between payoff to usual and surplus years of schooling; * = significant at the 5 percent level.

Consider first the analyses for foreign-born males with at least a Bachelor's degree (Appendix Table A.1). The estimates for the ORU model in this table are based on the RM procedure. Education is rewarded more highly in the more skilled occupations. Thus, there is a simple correlation coefficient of 0.74 between the payoff to actual years of education and the mean level of education (as a measure of overall skill) in the occupation. ${ }^{11}$ The payoff to years of usual education is positively correlated across occupations with the payoff to actual years of education $(r=0.50)$. There is no association, however, between the payoff to usual education and the mean level of education in the occupation $(r=0.16)$. Similarly, the association between the payoff to

\footnotetext{
${ }^{11}$ With only 18 occupations, the correlation coefficient would need to be at least 0.475 to be significant at the 5 percent level.
} 
years of surplus education and the mean level of education in the occupation is not statistically significant $(\mathrm{r}=0.32)$.

When the gap between the payoffs to years of surplus education and usual education is linked to the mean level of schooling, the simple correlation coefficient is -0.06 . That is, surplus schooling is used as effectively (or perhaps more to the point, as ineffectively) in high-skilled occupations as it is in less-skilled occupations. That is, there is minimal evidence that some sections of the economy are immune from the ineffective use of surplus schooling.

Similar patterns are evident for the native born in the Realized Matches procedure.

Moreover, the same findings emerge when the WSA procedure is used to construct the usual level of schooling for each occupation (see Table 5). The point estimates of the earnings effects in the ORU specification of the earnings functions estimated within each Census major group occupation are sensitive to whether the RM or WSA measure is used (see Appendix A). The material findings from the typical acrossoccupation analysis are not sensitive to which measure is used, as is clearly evident from the results in Tables 4 and $5 .^{12}$

12 The same conclusion is drawn from analyses (not reported here) that focus on the more highly skilled group of workers with at least a Master's degree. 
Table $5^{(\mathbf{a})}$

Correlation Coefficients among Payoffs of Education and Mean Level of Education from Analyses Disaggregated by Occupation, Skilled (Bachelor's or Higher Degree), Worker Self-Assessment Methodology, 25-64 Year Old Males, 2000 US Census

\begin{tabular}{|l|ccccc|}
\hline $\mathrm{FB} \backslash N \mathrm{NB}^{(\mathrm{b})}$ & EDUC & USUAL & OVER & GAP & MEAN \\
\hline EDUC & 1.00 & $0.64^{*}$ & $0.98^{*}$ & 0.21 & $0.85^{*}$ \\
USUAL & $0.72^{*}$ & 1.00 & $0.60^{*}$ & $0.88^{*}$ & $0.61^{*}$ \\
OVER & $0.96^{*}$ & $0.66^{*}$ & 1.00 & 0.15 & $0.83^{*}$ \\
GAP & 0.37 & $0.90^{*}$ & 0.27 & 1.00 & 0.26 \\
MEAN & $0.74^{*}$ & $0.50^{*}$ & $0.70^{*}$ & 0.23 & 1.00 \\
\hline
\end{tabular}

Source: Appendix A.

Notes: (a) Based on Worker Self-Assessment procedure; (b) Shaded cells are correlations for the foreign born; for other notes, see Table 4.

(b) Analyses by Level of Education

Vahey (2000) examined the incidence and returns to educational mismatch in Canada using the following variant of the ORU estimating equation:

$$
\ln Y_{i}=\beta_{0}+\beta_{1} \text { Over_Educ }{ }_{i}^{A}+\beta_{2} \text { Req_Educ }_{i}^{A}+\beta_{3} \text { Under_Educ }_{i}^{A}+\ldots+u_{i}
$$

where the superscript A on the ORU variables simply indicates an alternative definition. In particular, Vahey (2000) defined Req_Educ ${ }_{i}^{A}$ as a vector of dichotomous variables for each usual level of education. In the most general model considered, Over_Educ ${ }_{i}^{A}$ and Under_Educ $_{i}^{A}$ each contained dichotomous variables for each relevant combination of observed and usual levels of education. For example, for a usual level of education of “college/vocational school”, the attained education levels of Bachelor's degree and Postgraduate degree would each be represented by separate dichotomous over-education variables. In practice, however, the usual level of education was rarely more than one level from the actual level of education. Consequently, a restricted specification was employed where Over_Educ ${ }_{i}^{A}$ and Under_Educ ${ }_{i}^{A}$ comprised, for each usual level of 
schooling, single dichotomous variables for over-education and under-education. In the current analysis, however, the maximum detail on the extent of overeducation is incorporated into the estimating equation. For ease of exposition, these analyses are undertaken only for the sample of skilled workers with at least a Bachelor's degree. Moreover, as the interest in these analyses is on the comparisons of findings based on the RM and WSA procedures, only findings for the native born are presented. Findings for the foreign born essentially mirror those for the native born (Chiswick and Miller, 2009).

Given the array of findings from this approach, a graphical presentation of the main results will be used. Figure 1 presents the relevant findings for the native born based on the RM procedure, while Figure 2 presents findings for that birthplace group based on the WSA procedure.

Figures 1 and 2 have the logarithm of earnings on the vertical axis, and the usual level of education on the horizontal axis. The earnings—usual level of education profiles are presented for each of four actual levels of education: Bachelor's degree, Master's degree, Professional qualifications and Doctorates. The first line to consider in Figure 1 is the short line for workers with a Bachelor's degree that truncates at 16 years of usual education and which has the letters A-B-C positioned on it. 
Figure 1

Results from Dummy Variable Specification of ORU Model for Native Born, based on RM Procedure

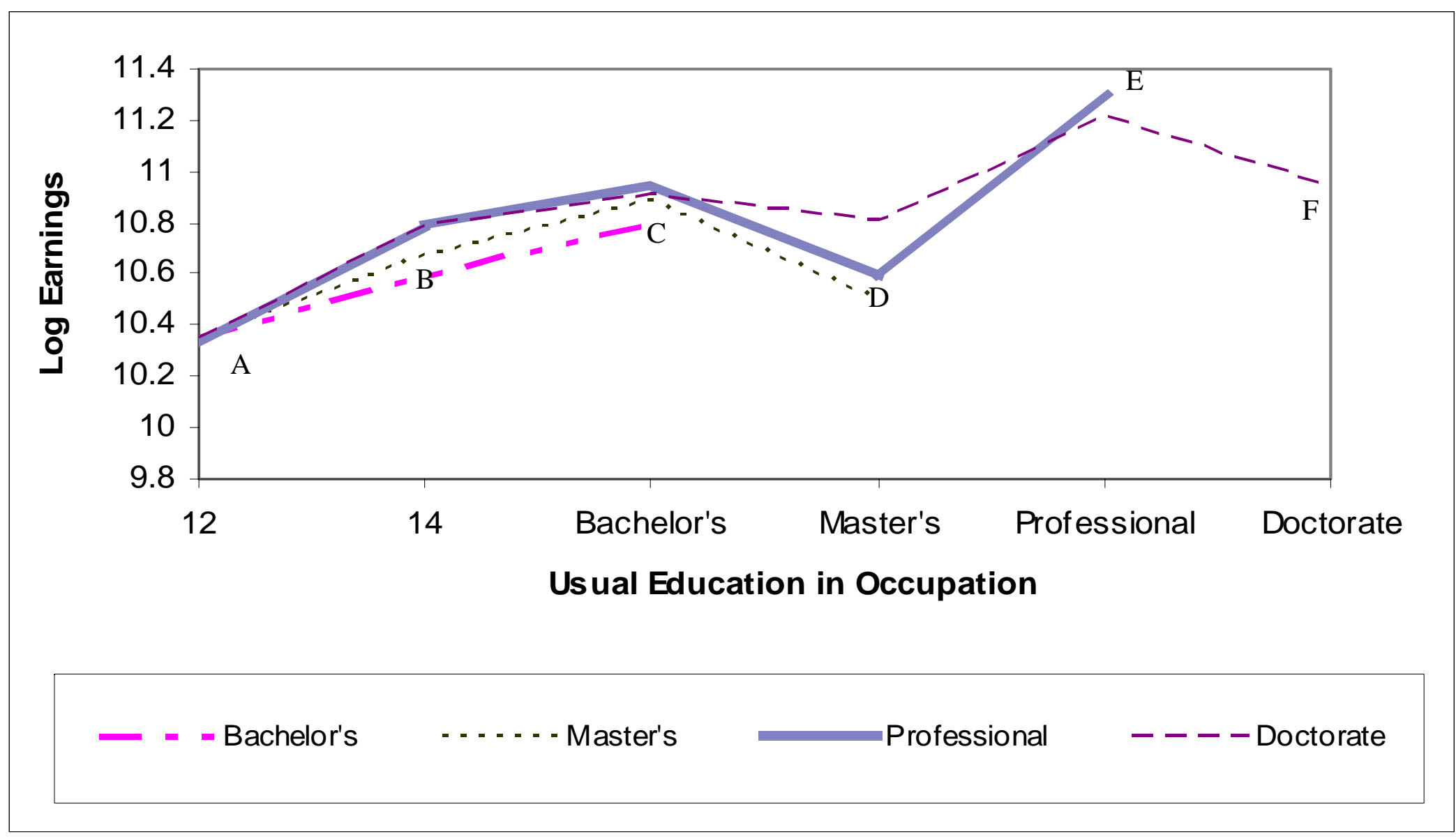


Figure 2

Results from Dummy Variable Specification of ORU Model for Native Born, based on WSA

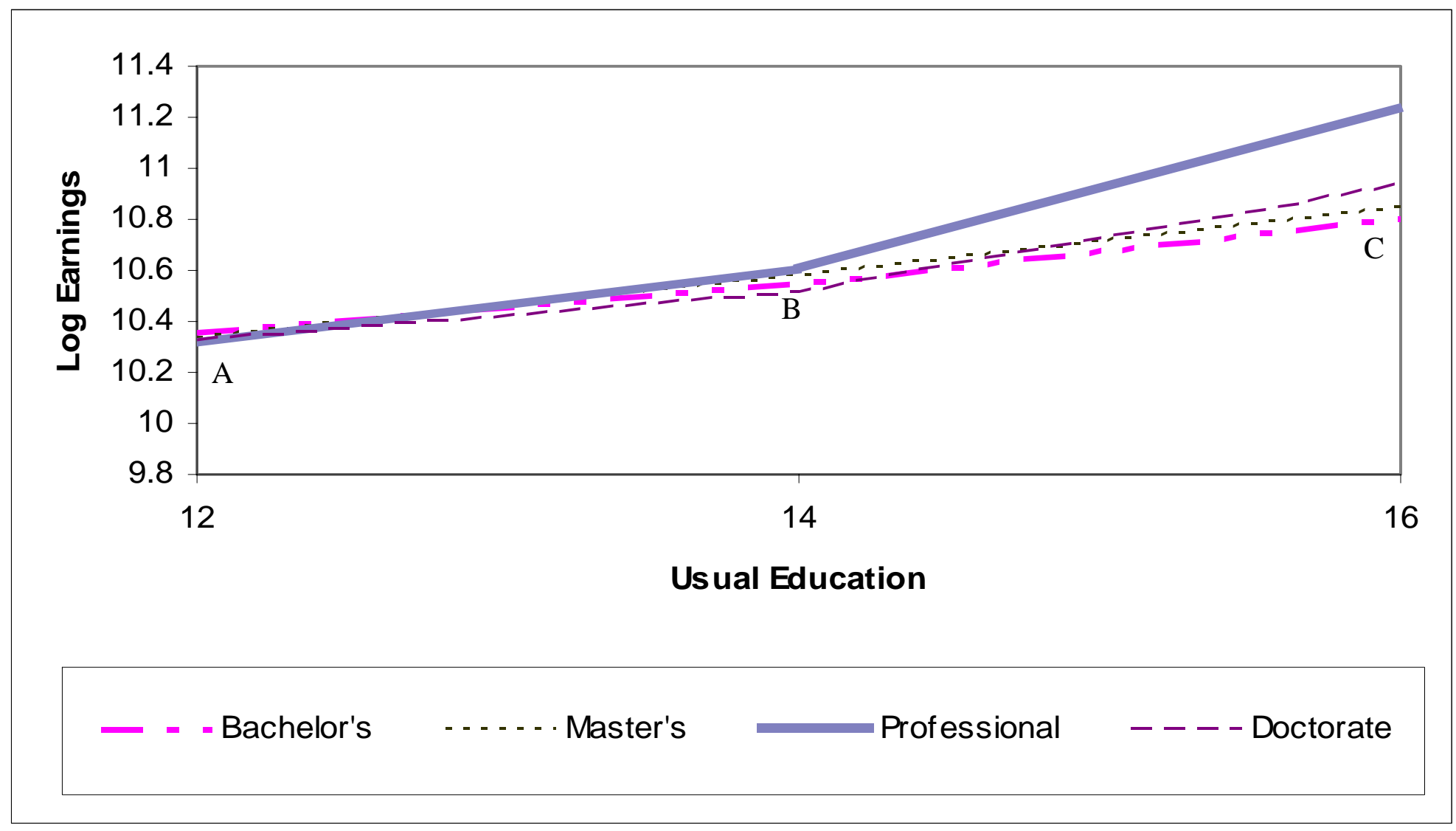


If workers with a Bachelor's degree are employed in an occupation where the usual level of education is 16 years they will be correctly matched in terms of educational attainment. These are represented in Figure 1 by the point C. If workers with a Bachelor's degree are employed in an occupation where the usual level of education is 12 or 14 years then they will be over-educated. Workers in these situations are represented in Figure 1 by the points $\mathrm{A}$ and $\mathrm{B}$, respectively. The highest earnings among workers with a Bachelor's degree occur when these workers are correctly matched to the educational level that is usual in the occupation in which they work (point C). The overeducated workers earn considerably less than the correctly matched workers. The fact that points A and B are lower than point C shows that years of surplus education are not used as effectively in the labor market as are years of correctly matched education among Bachelor's degree holders. The findings for the other levels of education generally follow that for workers with a Bachelor's degree. ${ }^{13}$

Thus, these analyses show that for skilled workers employed in occupations that require between 12 and 16 years of education, any surplus years of schooling will be used ineffectively, and the extent of ineffectiveness is largely invariant to the actual level of schooling. In the small group of occupations with usual levels of schooling greater than 16 years, the pattern of earnings effects is irregular. But they clearly support the view of earnings being more strongly related to the usual level of education for the job than to actual years of education. This conclusion carries over across to the analyses conducted using Vahey’s (2000) flexible specification of the earnings equation with the usual level

\footnotetext{
13 The Master's degree, and to a lesser extent Doctorates, appear to offer access to a particular set of occupations that are relatively poorly paid compared to those with a Bachelor's or Professional Degree.
} 
of schooling measured using the WSA procedure. Relevant details are illustrated in Figure 2.

\section{CONCLUSION}

This paper has provided an empirical assessment of the Realized Matches (RM) and Worker Self Assessment (WSA) measures of the usual or reference levels of schooling that is central to the ORU specification of the earnings equation. The analyses are conducted separately for adult male native-born and immigrant workers in the US, using 2000 US Census data and information from the O*NET data base. The RM approach uses the 2000 Census while the WSA approach uses the O*NET data to determine the usual level of schooling in the respondent's occupation. Analyses for each of these nativity groups are also conducted for two groups of skilled workers, by occupation, and by level of education.

Two main points emerge.

First, the point estimates of the earnings effects of the ORU variables are sensitive to the way the reference level of education is measured. This is more apparent the more narrowly defined is the sample that is used (e.g., a single occupation versus aggregatelevel analyses). Our experiments suggest that this is linked to the limited variability in the schooling levels available in the WSA measure compared to that in the RM measure.

Second, despite the variations in the point estimates, the same general patterns are found in the results based on the RM and WSA measures. As most research questions in this field of inquiry seem to be addressed through assessment of general patterns, this 
suggests that the same findings will be drawn from analyses based on these difference measures, as demonstrated through the study of three research questions in this paper.

These analyses are more detailed than those presented in Hartog (2000) and are based on more recent data. This should be very reassuring to researchers employing the ORU methodology to address specific issues—such as whether surplus skills can be utilized more effectively in certain occupations, or whether some post-secondary qualifications may be more general and hence can be utilized more effectively across a wider range of occupations. Thus, researchers using the ORU specification of the earnings equation should use their findings with a high degree of confidence. 


\section{REFERENCES}

Alpin, C., Shackleton, J.R. and Walsh, S. (1998). "Over- and Undereducation in the UK Graduate Labour Market”, Studies in Higher Education, Vol. 23(1), pp. 17-34.

Chiswick, Barry R. and Miller, Paul W., (2008). "Why is the Payoff to Schooling Smaller for Immigrants?”, Labour Economics, Vol. 15, No. 6, pp. 1317-1340.

Chiswick, Barry R. and Miller, Paul W., (2009). "Educational Mismatch: Are HighSkilled Immigrants Really Working at High-Skilled Jobs and the Price They Pay if They Aren't?", in Barry R. Chiswick ed. High Skilled Immigration in a Globalized Labor Market, Washington D.C.: American Enterprise Institute (forthcoming).

Duncan, Greg J. and Hoffman, Saul D., (1981), "The Incidence of Wage Effects of Overeducation”, Economics of Education Review, Vol. 1(1), pp. 75-86.

Hartog, Joop, (2000). "Over-education and Earnings: Where Are We, Where Should We Go?”, Economics of Education Review, Vol. 19, No. 2, pp. 131-147.

Kiker, Billy Frazier, Santos, Maria C. and de Oliveira, M Mendes, (1997). "Overeducation and Undereducation: Evidence for Portugal", Economics of Education Review, Vol. 16(2), pp. 111-125.

Kler, Parvinder, (2005). "Graduate Overeducation in Australia: A Comparison of the Mean and Objective Methods", Education Economics, Vol. 13, No. 1, pp. 47-72.

Rubb, Stephen, (2003), "Post-College Schooling, Overeducation, and Hourly Earnings in the United States”, Education Economics, Vol. 11(1), pp. 53-72.

Rumberger, Russell W., (1987), “The Impact of Surplus Schooling on Productivity and Earnings”, The Journal of Human Resources, Vol. 22(1), pp. 24-49.

Santos, Maria C., (1995), "Education and Earnings Differentials in Portugal”, $\mathrm{PhD}$ thesis, Faculty of Economics, Porto University, Porto, Portugal.

Tsang, Mun C., Rumberger, Russell W. and Levin, Henry M., (1991). "The Impact of Surplus Schooling on Worker Productivity”, Industrial Relations, Vol. 30(2), pp. 209-228.

Vahey, Shaun P. (2000), "The Great Canadian Training Robbery: Evidence on the Returns to Educational Mismatch”, Economics of Education Review, Vol. 19, pp. 219-227.

van der Meer, Peter H., (2006). "The Validity of Two Education Requirement Measures", Economics of Education Review, Vol. 25(2), pp. 211-219. 
Verdugo, Richard R. and Verdugo, Naomi T., (1989), "The Impact of Surplus Schooling on Earnings: Some Additional Findings", The Journal of Human Resources, Vol. 26(4), pp. 629-643. 
Table A.1 ${ }^{(a)}$

\section{Selected Estimates from Standard and ORU Models of Earnings by Occupation, Skilled (Bachelor's or Higher Degree) 25-64 Year Old Foreign-Born Males, 2000 US Census}

\begin{tabular}{|c|c|c|c|c|c|}
\hline Occupation & $\begin{array}{l}\text { Educational } \\
\text { Attainment }\end{array}$ & $\begin{array}{c}\text { Usual } \\
\text { Education }\end{array}$ & $\begin{array}{c}\text { Over- } \\
\text { education }\end{array}$ & $\begin{array}{l}\text { Mean of } \\
\text { Education }\end{array}$ & $\begin{array}{l}\text { Sample } \\
\text { Size }\end{array}$ \\
\hline $\begin{array}{l}\text { Management, Business and } \\
\text { Financial Operations }\end{array}$ & $\begin{array}{c}0.078 \\
(11.93)\end{array}$ & $\begin{array}{c}0.175 \\
(21.56)\end{array}$ & $\begin{array}{l}0.050 \\
(7.64)\end{array}$ & 16.914 & 15,175 \\
\hline $\begin{array}{l}\text { Business and Financial } \\
\text { Operations }\end{array}$ & $\begin{array}{l}0.099 \\
(8.81)\end{array}$ & $\begin{array}{l}0.149 \\
(7.15)\end{array}$ & $\begin{array}{l}0.098 \\
(8.69)\end{array}$ & 16.762 & 7,171 \\
\hline Professional and Related & $\begin{array}{l}0.038 \\
(6.47)\end{array}$ & $\begin{array}{c}0.146 \\
(13.27)\end{array}$ & $\begin{array}{l}0.028 \\
(4.76)\end{array}$ & 16.925 & 11,360 \\
\hline $\begin{array}{l}\text { Architecture and } \\
\text { Engineering }\end{array}$ & $\begin{array}{c}0.074 \\
(14.32)\end{array}$ & $\begin{array}{c}0.256 \\
(21.21)\end{array}$ & $\begin{array}{c}0.064 \\
(12.27)\end{array}$ & 16.992 & 9,231 \\
\hline $\begin{array}{l}\text { Life, Physical, and Social } \\
\text { Science }\end{array}$ & $\begin{array}{l}0.054 \\
(7.07)\end{array}$ & $\begin{array}{l}0.039 \\
(4.92)\end{array}$ & $\begin{array}{l}0.047 \\
(5.17)\end{array}$ & 18.464 & 3,133 \\
\hline Legal & $\begin{array}{l}0.132 \\
(5.78)\end{array}$ & $\begin{array}{l}0.173 \\
(6.82)\end{array}$ & $\begin{array}{l}0.079 \\
(2.08)\end{array}$ & 18.095 & 1,360 \\
\hline $\begin{array}{l}\text { Education, Training, and } \\
\text { Library }\end{array}$ & $\begin{array}{c}0.157 \\
(28.57)\end{array}$ & $\begin{array}{c}0.140 \\
(13.07)\end{array}$ & $\begin{array}{c}0.169 \\
(22.53)\end{array}$ & 18.095 & 6,769 \\
\hline $\begin{array}{l}\text { Arts, Design, Entertain., } \\
\text { Sports, and Media }\end{array}$ & $\begin{array}{l}0.031 \\
(1.62)\end{array}$ & $\begin{array}{l}0.047 \\
(1.51)\end{array}$ & $\begin{array}{l}0.031 \\
(1.63)\end{array}$ & 16.724 & 3,071 \\
\hline $\begin{array}{l}\text { Healthcare Practitioner and } \\
\text { Technical }\end{array}$ & $\begin{array}{c}0.174 \\
(22.92)\end{array}$ & $\begin{array}{c}0.224 \\
(30.99)\end{array}$ & $\begin{array}{l}0.016 \\
(1.52)\end{array}$ & 18.023 & 9,384 \\
\hline Healthcare Support & $\begin{array}{l}0.156 \\
(5.14)\end{array}$ & $\begin{array}{l}0.209 \\
(3.63)\end{array}$ & $\begin{array}{l}0.152 \\
(4.99)\end{array}$ & 16.978 & 495 \\
\hline Protective Service & $\begin{array}{l}0.016 \\
(0.56)\end{array}$ & $\begin{array}{l}0.159 \\
(5.28)\end{array}$ & $\begin{array}{l}0.002 \\
(0.06)\end{array}$ & 16.515 & 1,088 \\
\hline Food Preparation & $\begin{array}{l}-0.011 \\
(0.61)\end{array}$ & $\begin{array}{l}0.109 \\
(3.45)\end{array}$ & $\begin{array}{l}-0.014 \\
(0.75)\end{array}$ & 16.549 & 1,901 \\
\hline Personal Care and Service & $\begin{array}{l}0.004 \\
(0.12)\end{array}$ & $\begin{array}{l}0.064 \\
(1.78)\end{array}$ & $\begin{array}{l}0.001 \\
(0.05)\end{array}$ & 16.541 & 730 \\
\hline Sales and Related & $\begin{array}{l}0.051 \\
(4.42)\end{array}$ & $\begin{array}{c}0.155 \\
(12.19)\end{array}$ & $\begin{array}{l}0.045 \\
(3.96)\end{array}$ & 16.545 & 9,578 \\
\hline $\begin{array}{l}\text { Office and Administrative } \\
\text { Support }\end{array}$ & $\begin{array}{l}0.053 \\
(5.06)\end{array}$ & $\begin{array}{c}0.172 \\
(11.81)\end{array}$ & $\begin{array}{l}0.053 \\
(4.99)\end{array}$ & 16.546 & 5,506 \\
\hline Construction and Extraction & $\begin{array}{l}-0.010 \\
(0.57)\end{array}$ & $\begin{array}{l}-0.005 \\
(0.14)\end{array}$ & $\begin{array}{l}-0.010 \\
(0.57)\end{array}$ & 16.622 & 2,413 \\
\hline $\begin{array}{l}\text { Installation, Maintenance, } \\
\text { and Repair }\end{array}$ & $\begin{array}{l}0.034 \\
(1.82)\end{array}$ & $\begin{array}{l}0.062 \\
(2.34)\end{array}$ & $\begin{array}{l}0.036 \\
(1.93)\end{array}$ & 16.524 & 2,230 \\
\hline $\begin{array}{l}\text { Production, Transport. and } \\
\text { Material Moving }\end{array}$ & $\begin{array}{l}0.069 \\
(5.57)\end{array}$ & $\begin{array}{l}0.092 \\
(2.07)\end{array}$ & $\begin{array}{l}0.069 \\
(5.55)\end{array}$ & 16.583 & 3,824 \\
\hline $\begin{array}{l}\text { Transportation and Material } \\
\text { Moving }\end{array}$ & $\begin{array}{l}-0.005 \\
(0.32)\end{array}$ & $\begin{array}{l}0.130 \\
(5.95)\end{array}$ & $\begin{array}{l}-0.005 \\
(0.34)\end{array}$ & 16.583 & 3,123 \\
\hline
\end{tabular}

Source: 2000 Census, 5\% PUMS.

Notes: (a) Based on Realized Matches Procedure; heteroskedasticity-consistent 't' statistics in parentheses. The other variables held constant in the regression are the same as those indicated in Table 1. 
Table A. ${ }^{\text {(a) }}$

Selected Estimates from Standard and ORU Models of Earnings by Occupation, Skilled (Bachelor's or Higher Degree) 25-64 Year Old Native-Born Males, 2000 US

\section{Census}

\begin{tabular}{|c|c|c|c|c|c|}
\hline Occupation & $\begin{array}{l}\text { Educational } \\
\text { Attainment }\end{array}$ & $\begin{array}{c}\text { Usual } \\
\text { Education }\end{array}$ & $\begin{array}{c}\text { Over- } \\
\text { education }\end{array}$ & $\begin{array}{c}\text { Mean of } \\
\text { Education }\end{array}$ & $\begin{array}{l}\text { Sample } \\
\text { Size }\end{array}$ \\
\hline $\begin{array}{l}\text { Management, Business and } \\
\text { Financial Operations }\end{array}$ & $\begin{array}{l}0.065 \\
(9.27)\end{array}$ & $\begin{array}{c}0.133 \\
(16.51)\end{array}$ & $\begin{array}{l}0.017 \\
(2.34)\end{array}$ & 16.627 & 19,193 \\
\hline $\begin{array}{l}\text { Business and Financial } \\
\text { Operations }\end{array}$ & $\begin{array}{l}0.080 \\
(6.69)\end{array}$ & $\begin{array}{l}0.157 \\
(9.40)\end{array}$ & $\begin{array}{l}0.077 \\
(6.42)\end{array}$ & 16.486 & 9,722 \\
\hline Professional and Related & $\begin{array}{l}0.058 \\
(5.67)\end{array}$ & $\begin{array}{l}0.132 \\
(9.23)\end{array}$ & $\begin{array}{l}0.045 \\
(4.41)\end{array}$ & 16.461 & 5,182 \\
\hline $\begin{array}{l}\text { Architecture and } \\
\text { Engineering }\end{array}$ & $\begin{array}{l}0.044 \\
(4.94)\end{array}$ & $\begin{array}{c}0.233 \\
(15.06)\end{array}$ & $\begin{array}{l}0.378 \\
(4.22)\end{array}$ & 16.497 & 6,060 \\
\hline $\begin{array}{l}\text { Life, Physical, and Social } \\
\text { Science }\end{array}$ & $\begin{array}{l}0.087 \\
(9.57)\end{array}$ & $\begin{array}{l}0.080 \\
(8.50)\end{array}$ & $\begin{array}{l}0.093 \\
(8.64)\end{array}$ & 17.469 & 2,398 \\
\hline Legal & $\begin{array}{l}0.155 \\
(7.92)\end{array}$ & $\begin{array}{l}0.148 \\
(6.40)\end{array}$ & $\begin{array}{l}0.020 \\
(0.57)\end{array}$ & 18.312 & 4,498 \\
\hline $\begin{array}{l}\text { Education, Training, and } \\
\text { Library }\end{array}$ & $\begin{array}{c}0.100 \\
(21.71)\end{array}$ & $\begin{array}{l}0.071 \\
(7.50)\end{array}$ & $\begin{array}{c}0.098 \\
(16.03)\end{array}$ & 17.295 & 9,878 \\
\hline $\begin{array}{l}\text { Arts, Design, Entertain., } \\
\text { Sports, and Media }\end{array}$ & $\begin{array}{l}-0.029 \\
(1.12)\end{array}$ & $\begin{array}{l}0.008 \\
(0.19)\end{array}$ & $\begin{array}{l}-0.030 \\
(1.16)\end{array}$ & 16.438 & 3,635 \\
\hline $\begin{array}{l}\text { Healthcare Practitioner and } \\
\text { Technical }\end{array}$ & $\begin{array}{c}0.230 \\
(25.71)\end{array}$ & $\begin{array}{c}0.263 \\
(30.56)\end{array}$ & $\begin{array}{l}0.081 \\
(5.95)\end{array}$ & 17.898 & 6,299 \\
\hline Healthcare Support & $\begin{array}{l}0.233 \\
(3.90)\end{array}$ & $\begin{array}{l}0.073 \\
(0.76)\end{array}$ & $\begin{array}{l}0.228 \\
(3.87)\end{array}$ & 16.776 & 226 \\
\hline Protective Service & $\begin{array}{l}0.007 \\
(0.34)\end{array}$ & $\begin{array}{l}0.115 \\
(4.64)\end{array}$ & $\begin{array}{l}0.012 \\
(0.58)\end{array}$ & 16.269 & 2,499 \\
\hline Food Preparation & $\begin{array}{l}-0.018 \\
(0.46)\end{array}$ & $\begin{array}{l}0.121 \\
(2.35)\end{array}$ & $\begin{array}{l}-0.013 \\
(0.34)\end{array}$ & 16.279 & 731 \\
\hline Personal Care and Service & $\begin{array}{l}0.074 \\
(1.63)\end{array}$ & $\begin{array}{l}0.083 \\
(1.71)\end{array}$ & $\begin{array}{l}0.074 \\
(1.63)\end{array}$ & 16.423 & 742 \\
\hline Sales and Related & $\begin{array}{l}0.024 \\
(1.49)\end{array}$ & $\begin{array}{l}0.127 \\
(7.80)\end{array}$ & $\begin{array}{l}0.022 \\
(1.36)\end{array}$ & 16.287 & 11,704 \\
\hline $\begin{array}{l}\text { Office and Administrative } \\
\text { Support }\end{array}$ & $\begin{array}{l}0.048 \\
(3.19)\end{array}$ & $\begin{array}{l}0.160 \\
(9.08)\end{array}$ & $\begin{array}{l}0.041 \\
(2.74)\end{array}$ & 16.349 & 5,299 \\
\hline Construction and Extraction & $\begin{array}{l}0.013 \\
(0.57)\end{array}$ & $\begin{array}{l}-0.021 \\
(0.34)\end{array}$ & $\begin{array}{l}0.012 \\
(0.53)\end{array}$ & 16.316 & 2,183 \\
\hline $\begin{array}{l}\text { Installation, Maintenance, } \\
\text { and Repair }\end{array}$ & $\begin{array}{l}-0.050 \\
(1.43)\end{array}$ & $\begin{array}{l}-0.073 \\
(1.90)\end{array}$ & $\begin{array}{l}-0.049 \\
(1.42)\end{array}$ & 16.268 & 1,439 \\
\hline $\begin{array}{l}\text { Production, Transport. and } \\
\text { Material Moving }\end{array}$ & $\begin{array}{l}0.023 \\
(0.97)\end{array}$ & $\begin{array}{l}-0.079 \\
(0.63)\end{array}$ & $\begin{array}{l}0.024 \\
(1.01)\end{array}$ & 16.341 & 2,307 \\
\hline $\begin{array}{l}\text { Transportation and Material } \\
\text { Moving }\end{array}$ & $\begin{array}{l}-0.008 \\
(0.28)\end{array}$ & $\begin{array}{l}0.178 \\
(6.64)\end{array}$ & $\begin{array}{l}-0.012 \\
(0.47)\end{array}$ & 16.299 & 2,406 \\
\hline
\end{tabular}

Source: 2000 Census, 5\% PUMS.

Notes: (a) Based on Realized Matches Procedure; heteroskedasticity-consistent 't' statistics in parentheses. The other variables held constant in the regression are the same as those indicated in Table 1. 
Table A.3 ${ }^{(\mathbf{a})}$

\section{Selected Estimates from Standard and ORU Models of Earnings by Occupation, Skilled (Bachelor's or Higher Degree) 25-64 Year Old Foreign-Born Males, 2000 US Census}

\begin{tabular}{|c|c|c|c|c|c|}
\hline Occupation & $\begin{array}{l}\text { Educational } \\
\text { Attainment }\end{array}$ & $\begin{array}{c}\text { Usual } \\
\text { Education }\end{array}$ & $\begin{array}{c}\text { Over- } \\
\text { education }\end{array}$ & $\begin{array}{l}\text { Mean of } \\
\text { Education }\end{array}$ & $\begin{array}{l}\text { Sample } \\
\text { Size }\end{array}$ \\
\hline $\begin{array}{l}\text { Management, Business and } \\
\text { Financial Operations }\end{array}$ & $\begin{array}{c}0.078 \\
(11.93)\end{array}$ & $\begin{array}{l}0.330 \\
(25.93)\end{array}$ & $\begin{array}{l}0.057 \\
(8.84)\end{array}$ & 16.914 & 15,175 \\
\hline $\begin{array}{l}\text { Business and Financial } \\
\text { Operations }\end{array}$ & $\begin{array}{l}0.099 \\
(8.81)\end{array}$ & $\begin{array}{l}0.181 \\
(9.79)\end{array}$ & $\begin{array}{l}0.097 \\
(8.62)\end{array}$ & 16.762 & 7,171 \\
\hline Professional and Related & $\begin{array}{l}0.038 \\
(6.47)\end{array}$ & $\begin{array}{c}0.170 \\
(15.30)\end{array}$ & $\begin{array}{l}0.031 \\
(5.27)\end{array}$ & 16.925 & 11,360 \\
\hline Architecture and Engineering & $\begin{array}{c}0.074 \\
(14.32)\end{array}$ & $\begin{array}{c}0.272 \\
(16.81)\end{array}$ & $\begin{array}{c}0.068 \\
(13.06)\end{array}$ & 16.992 & 9,231 \\
\hline $\begin{array}{l}\text { Life, Physical, and Social } \\
\text { Science }\end{array}$ & $\begin{array}{l}0.054 \\
(7.07)\end{array}$ & $\begin{array}{l}0.125 \\
(5.17)\end{array}$ & $\begin{array}{l}0.050 \\
(6.49)\end{array}$ & 18.464 & 3,133 \\
\hline Legal & $\begin{array}{l}0.132 \\
(5.78)\end{array}$ & $\begin{array}{l}0.296 \\
(8.35)\end{array}$ & $\begin{array}{l}0.092 \\
(3.76)\end{array}$ & 18.095 & 1,360 \\
\hline $\begin{array}{l}\text { Education, Training, and } \\
\text { Library }\end{array}$ & $\begin{array}{c}0.157 \\
(28.57)\end{array}$ & $\begin{array}{l}0.350 \\
(9.02)\end{array}$ & $\begin{array}{c}0.153 \\
(28.01)\end{array}$ & 18.095 & 6,769 \\
\hline $\begin{array}{l}\text { Arts, Design, Entertain., } \\
\text { Sports, and Media }\end{array}$ & $\begin{array}{l}0.031 \\
(1.62)\end{array}$ & $\begin{array}{l}0.014 \\
(0.44)\end{array}$ & $\begin{array}{l}0.032 \\
(1.66)\end{array}$ & 16.724 & 3,071 \\
\hline $\begin{array}{l}\text { Healthcare Practitioner and } \\
\text { Technical }\end{array}$ & $\begin{array}{c}0.174 \\
(22.92)\end{array}$ & $\begin{array}{c}0.304 \\
(27.79)\end{array}$ & $\begin{array}{c}0.121 \\
(13.97)\end{array}$ & 18.023 & 9,384 \\
\hline Healthcare Support & $\begin{array}{l}0.156 \\
(5.14)\end{array}$ & $\begin{array}{l}0.203 \\
(2.56)\end{array}$ & $\begin{array}{l}0.157 \\
(5.17)\end{array}$ & 16.978 & 495 \\
\hline Protective Service & $\begin{array}{l}0.016 \\
(0.56)\end{array}$ & $\begin{array}{l}0.188 \\
(6.52)\end{array}$ & $\begin{array}{l}-0.002 \\
(0.08)\end{array}$ & 16.515 & 1,088 \\
\hline Food Preparation & $\begin{array}{l}-0.011 \\
(0.61)\end{array}$ & $\begin{array}{l}0.010 \\
(0.40)\end{array}$ & $\begin{array}{l}-0.012 \\
(0.63)\end{array}$ & 16.549 & 1,901 \\
\hline Personal Care and Service & $\begin{array}{l}0.004 \\
(0.12)\end{array}$ & $\begin{array}{l}0.026 \\
(0.72)\end{array}$ & $\begin{array}{l}0.003 \\
(0.09)\end{array}$ & 16.541 & 730 \\
\hline Sales and Related & $\begin{array}{l}0.051 \\
(4.42)\end{array}$ & $\begin{array}{c}0.154 \\
(12.43)\end{array}$ & $\begin{array}{l}0.041 \\
(3.66)\end{array}$ & 16.545 & 9,578 \\
\hline $\begin{array}{l}\text { Office and Administrative } \\
\text { Support }\end{array}$ & $\begin{array}{l}0.053 \\
(5.06)\end{array}$ & $\begin{array}{l}0.117 \\
(8.12)\end{array}$ & $\begin{array}{l}0.053 \\
(5.02)\end{array}$ & 16.546 & 5,506 \\
\hline Construction and Extraction & $\begin{array}{l}-0.010 \\
(0.57)\end{array}$ & $\begin{array}{l}0.086 \\
(3.35)\end{array}$ & $\begin{array}{l}-0.012 \\
(0.74)\end{array}$ & 16.622 & 2,413 \\
\hline $\begin{array}{l}\text { Installation, Maintenance, } \\
\text { and Repair }\end{array}$ & $\begin{array}{l}0.034 \\
(1.82)\end{array}$ & $\begin{array}{l}0.135 \\
(5.13)\end{array}$ & $\begin{array}{l}0.028 \\
(1.54)\end{array}$ & 16.524 & 2,230 \\
\hline $\begin{array}{l}\text { Production, Transport. and } \\
\text { Material Moving }\end{array}$ & $\begin{array}{l}0.069 \\
(5.57)\end{array}$ & $\begin{array}{l}0.156 \\
(8.84)\end{array}$ & $\begin{array}{l}0.064 \\
(5.18)\end{array}$ & 16.583 & 3,824 \\
\hline $\begin{array}{l}\text { Transportation and Material } \\
\text { Moving }\end{array}$ & $\begin{array}{l}-0.005 \\
(0.32)\end{array}$ & $\begin{array}{l}0.157 \\
(7.59)\end{array}$ & $\begin{array}{l}-0.007 \\
(0.52)\end{array}$ & 16.583 & 3,123 \\
\hline
\end{tabular}

Source: 2000 Census, 5\% PUMS.

Notes: (a) Based on Worker Self-Assessment; heteroskedasticity-consistent 't' statistics in parentheses.

The other variables held constant in the regression are the same as those indicated in Table 1. 
Table A. $4^{\text {(a) }}$

Selected Estimates from Standard and ORU Models of Earnings by Occupation, Skilled (Bachelor's or Higher Degree) 25-64 Year Old Native-Born Males, 2000 US Census

\begin{tabular}{|c|c|c|c|c|c|}
\hline Occupation & $\begin{array}{l}\text { Educational } \\
\text { Attainment }\end{array}$ & $\begin{array}{c}\text { Usual } \\
\text { Education }\end{array}$ & $\begin{array}{c}\text { Over- } \\
\text { education }\end{array}$ & $\begin{array}{l}\text { Mean of } \\
\text { Education }\end{array}$ & $\begin{array}{l}\text { Sample } \\
\text { Size }\end{array}$ \\
\hline $\begin{array}{l}\text { Management, Business and } \\
\text { Financial Operations }\end{array}$ & $\begin{array}{l}0.065 \\
(9.27)\end{array}$ & $\begin{array}{c}0.310 \\
(23.41)\end{array}$ & $\begin{array}{l}0.040 \\
(5.80)\end{array}$ & 16.627 & 19,193 \\
\hline $\begin{array}{l}\text { Business and Financial } \\
\text { Operations }\end{array}$ & $\begin{array}{l}0.080 \\
(6.69)\end{array}$ & $\begin{array}{c}0.168 \\
(11.30)\end{array}$ & $\begin{array}{l}0.074 \\
(6.16)\end{array}$ & 16.486 & 9,722 \\
\hline Professional and Related & $\begin{array}{l}0.058 \\
(5.67)\end{array}$ & $\begin{array}{c}0.165 \\
(11.71)\end{array}$ & $\begin{array}{l}0.050 \\
(4.83)\end{array}$ & 16.461 & 5,182 \\
\hline $\begin{array}{l}\text { Architecture and } \\
\text { Engineering }\end{array}$ & $\begin{array}{l}0.044 \\
(4.94)\end{array}$ & $\begin{array}{c}0.232 \\
(12.36)\end{array}$ & $\begin{array}{l}0.040 \\
(4.51)\end{array}$ & 16.497 & 6,060 \\
\hline $\begin{array}{l}\text { Life, Physical, and Social } \\
\text { Science }\end{array}$ & $\begin{array}{l}0.087 \\
(9.57)\end{array}$ & $\begin{array}{l}0.051 \\
(1.54)\end{array}$ & $\begin{array}{l}0.088 \\
(9.61)\end{array}$ & 17.469 & 2,398 \\
\hline Legal & $\begin{array}{l}0.155 \\
(7.92)\end{array}$ & $\begin{array}{l}0.313 \\
(8.50)\end{array}$ & $\begin{array}{l}0.121 \\
(5.58)\end{array}$ & 18.312 & 4,498 \\
\hline $\begin{array}{l}\text { Education, Training, and } \\
\text { Library }\end{array}$ & $\begin{array}{c}0.100 \\
(21.71)\end{array}$ & $\begin{array}{l}0.380 \\
(9.14)\end{array}$ & $\begin{array}{c}0.098 \\
(21.30)\end{array}$ & 17.295 & 9,878 \\
\hline $\begin{array}{l}\text { Arts, Design, Entertain., } \\
\text { Sports, and Media }\end{array}$ & $\begin{array}{l}-0.029 \\
(1.12)\end{array}$ & $\begin{array}{l}0.040 \\
(1.17)\end{array}$ & $\begin{array}{l}-0.034 \\
(1.32)\end{array}$ & 16.438 & 3,635 \\
\hline $\begin{array}{l}\text { Healthcare Practitioner and } \\
\text { Technical }\end{array}$ & $\begin{array}{c}0.230 \\
(25.71)\end{array}$ & $\begin{array}{l}0.347 \\
(26.85)\end{array}$ & $\begin{array}{c}0.182 \\
(18.21)\end{array}$ & 17.898 & 6,299 \\
\hline Healthcare Support & $\begin{array}{l}0.233 \\
(3.90)\end{array}$ & $\begin{array}{l}0.095 \\
(0.98)\end{array}$ & $\begin{array}{l}0.225 \\
(3.79)\end{array}$ & 16.776 & 226 \\
\hline Protective Service & $\begin{array}{l}0.007 \\
(0.34)\end{array}$ & $\begin{array}{l}0.150 \\
(6.87)\end{array}$ & $\begin{array}{l}0.005 \\
(0.28)\end{array}$ & 16.269 & 2,499 \\
\hline Food Preparation & $\begin{array}{l}-0.018 \\
(0.46)\end{array}$ & $\begin{array}{l}-0.012 \\
(0.26)\end{array}$ & $\begin{array}{l}-0.018 \\
(0.46)\end{array}$ & 16.279 & 731 \\
\hline Personal Care and Service & $\begin{array}{l}0.074 \\
(1.63)\end{array}$ & $\begin{array}{l}0.074 \\
(1.56)\end{array}$ & $\begin{array}{l}0.074 \\
(1.62)\end{array}$ & 16.423 & 742 \\
\hline Sales and Related & $\begin{array}{l}0.024 \\
(1.49)\end{array}$ & $\begin{array}{l}0.127 \\
(7.81)\end{array}$ & $\begin{array}{l}0.017 \\
(1.09)\end{array}$ & 16.287 & 11,704 \\
\hline $\begin{array}{l}\text { Office and Administrative } \\
\text { Support }\end{array}$ & $\begin{array}{l}0.048 \\
(3.19)\end{array}$ & $\begin{array}{l}0.109 \\
(6.36)\end{array}$ & $\begin{array}{l}0.044 \\
(2.91)\end{array}$ & 16.349 & 5,299 \\
\hline Construction and Extraction & $\begin{array}{l}0.013 \\
(0.57)\end{array}$ & $\begin{array}{l}0.113 \\
(3.86)\end{array}$ & $\begin{array}{l}0.013 \\
(0.58)\end{array}$ & 16.316 & 2,183 \\
\hline $\begin{array}{l}\text { Installation, Maintenance, } \\
\text { and Repair }\end{array}$ & $\begin{array}{l}-0.050 \\
(1.43)\end{array}$ & $\begin{array}{l}0.063 \\
(1.53)\end{array}$ & $\begin{array}{l}-0.052 \\
(1.50)\end{array}$ & 16.268 & 1,439 \\
\hline $\begin{array}{l}\text { Production, Transport. and } \\
\text { Material Moving }\end{array}$ & $\begin{array}{l}0.023 \\
(0.97)\end{array}$ & $\begin{array}{l}0.152 \\
(4.85)\end{array}$ & $\begin{array}{l}0.017 \\
(0.74)\end{array}$ & 16.341 & 2,307 \\
\hline $\begin{array}{l}\text { Transportation and Material } \\
\text { Moving }\end{array}$ & $\begin{array}{l}-0.008 \\
(0.28)\end{array}$ & $\begin{array}{l}0.210 \\
(7.88)\end{array}$ & $\begin{array}{l}-0.011 \\
(0.43)\end{array}$ & 16.299 & 2,406 \\
\hline
\end{tabular}

Source: 2000 Census, 5\% PUMS.

Notes: (a) Based on Worker Self-Assessment; heteroskedasticity-consistent 't' statistics in parentheses.

The other variables held constant in the regression are the same as those indicated in Table 1. 